\title{
Site of Protonation of Benzonitrile \\ Hydrogen Interchange in the Protonated Species
}

\author{
H. Wincel \\ Polish Academy of Science, Institute of Physical Chemistry, Warszawa, Poland
}

\author{
R. H. Fokkens and N. M. M. Nibbering \\ Institute of Mass Spectrometry, University of Amsterdam, Amsterdam, The Netherlands
}

\begin{abstract}
The site of protonation of gaseous benzonitrile in reactions with $\mathrm{H}_{3}^{+}, \mathrm{CH}_{3} \mathrm{OH}_{2}^{+}$, and $\mathrm{CH}_{3} \mathrm{CNH}^{+}$as protonating agents has been examined by using tandem mass spectrometry in combination with deuterium and ${ }^{13} \mathrm{C}$ labeling. Metastable and collision-induced dissociation studies of $\mathrm{C}_{6} \mathrm{X}_{5} \mathrm{CNX}^{+}(\mathrm{X}=\mathrm{H}$ or $\mathrm{D})$ show that proton attachment occurs on the $\mathrm{CN}$ group. The metastably decomposing $\mathrm{C}_{6} \mathrm{X}_{5} \mathrm{CNX} \mathrm{X}^{+}$leads only to $\mathrm{C}_{6} \mathrm{X}_{5}{ }^{+}+\mathrm{XCN}$. This reaction proceeds via a mechanism involving $\mathrm{H}^{+}\left(\mathrm{D}^{+}\right)$transfer from the $\mathrm{CN}$ group to the phenyl ring in which $\mathrm{H} / \mathrm{D}$ exchange occurs. The efficiency of the $\mathrm{CN}$-to-ring $\mathrm{H}^{+}\left(\mathrm{D}^{+}\right)$transfer increases in the order para $<$ meta < ortho position. Evidence for incomplete H/D atom randomization in $\mathrm{C}_{6} \mathrm{X}_{5} \mathrm{CNX}^{+}$prior to $\mathrm{XCN}$ loss has been obtained. Both processes, $\mathrm{CN}$-toring $\mathrm{H} / \mathrm{D}$ exchange and $\mathrm{H} / \mathrm{D}$ exchange at the phenyl ring, are affected by the internal energy of the $\mathrm{C}_{6} \mathrm{X}_{5} \mathrm{CNX}^{+}$ions. The results have been interpreted in terms of the internal energy distribution of the ions fragmenting within the metastable time window. Collision-induced dissociation of $\mathrm{C}_{6} \mathrm{X}_{5} \mathrm{CNX}^{+}$causes the energy-enriched ions to decompose by direct bond cleavage into $\mathrm{C}_{6} \mathrm{X}_{5}^{+}+\mathrm{XNC}$. (J Am Soc Mass Spectrom 1990, 1, 225-232)
\end{abstract}

I

ntermolecular proton transfer and intramolecular hydrogen or proton migrations are of considerable importance for the elucidation of mechanistic details of organic reactions. It is therefore not surprising that these processes have been the subject of many investigations [1] in the field of gas-phase ion chemistry.

This paper reports a detailed study of the initial site of protonation of benzonitrile and the unimolecular chemistry of the protonated (deuterated) species. Our interest in this problem was stimulated by a controversy in the literature [2-4] regarding the site of protonation. In the study of H/D exchange reactions of protonated aromatic compounds with $\mathrm{D}_{2} \mathrm{O}$ by ion cyclotron resonance spectroscopy, Beauchamp and coworkers [2] noted that with sufficiently acidic donors, for example, $\mathrm{D}_{3} \mathrm{O}^{+}$, protonation of benzonitrile occurs on both the ring and the substituent. Lau and Kebarle [3] argued on the basis of proton transfer equilibrium measurements that the $\mathrm{CN}$ group is protonated. On the other hand, more recently Meot-Ner and coworkers [4] stated that ring protonation is energetically favored over $\mathrm{CN}$ protonation.

To obtain direct experimental evidence on proton exchange reactions in protonated benzonitrile, we studied its metastable ion (MI) and collision-induced dissociations (CID) by mass-analyzed ion kinetic en-

Address reprint requests to Professor N. M. M. Nibbering, Institute of Mass Spectrometry, University of Amsterdam, Nieuwe Achtergracht 129, 1018 WS Amsterdam, The Netherlands. ergy (MIKE) spectroscopy in combination with deuterium and ${ }^{13} \mathrm{C}$ labeling experiments. To provide additional information concerning the reaction mechanism, these species were produced in reactions of different protonation exothermicity under chemical ionization (CI) conditions.

\section{Experimental}

All experiments were carried out with a VG ZAB-2HF mass spectrometer that was coupled to a VG 11/250 data system (VG Analytical Ltd., Manchester, UK) using the $\mathrm{CI}$ source and techniques identical to those applied in our previous studies $[5,6]$. Only a brief description of the experimental conditions will be given here.

The ion source was operated under the following conditions: accelerating voltage, $8 \mathrm{kV}$; ionizing electron energy, $70 \mathrm{eV}$; ion repeller potential with respect to the source chamber, $0 \mathrm{~V}$; ion source temperature, $\sim 180$ ${ }^{\circ} \mathrm{C}$. The protonated benzonitrile ions, $\left(\mathrm{C}_{6} \mathrm{X}_{5} \mathrm{CN}\right) \mathrm{X}^{+}$ (where $\mathrm{X}=\mathrm{H}$ and $\mathrm{D}$ ), were generated by $\mathrm{CI}$ of benzonitrile 1 and the analogues labeled with ${ }^{13} \mathrm{C}$ and deuterium, 1a-1e (Scheme I), using $\mathrm{H}_{2}, \mathrm{D}_{2}, \mathrm{CH}_{3} \mathrm{OH}$, $\mathrm{CD}_{3} \mathrm{OD}$, and $\mathrm{CD}_{3} \mathrm{CN}$ as reagent gases. The typical concentration of benzonitrile inside the source was $\sim 3 \times 10^{12}$ molecules $/ \mathrm{cm}^{3}$, that is, $\sim 1 \times 10^{-4} \mathrm{mbar}$, as estimated [5] from the reading of the ionization gauge 


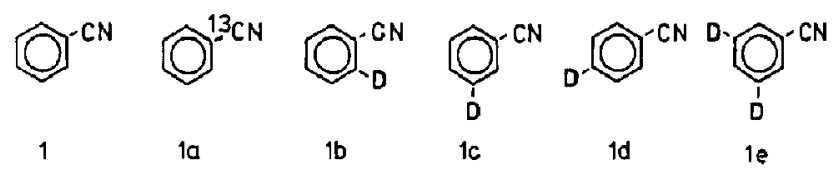

Scheme I

at the entrance to the diffusion pump $\left(P_{i}=2 \times 10^{-7}\right.$ mbar); the total source pressure was sufficient to give an ionization gauge reading of $\sim 10^{-6}$ mbar.

Under these conditions, peaks due to ions with a relative abundance $\geq 10 \%$ are observed at $m / z 19$ $(23 \%), m / z 103(60 \%)$, and $m / z 104(100 \%)$ in the spectrum of the $\mathrm{H}_{2}-\mathrm{C}_{6} \mathrm{H}_{5} \mathrm{CN}$ mixture; at $m / z 15(16 \%), m / z$ $29(18 \%), m / z 31(31 \%), m / z 32(13 \%), m / z 33(100 \%)$, $m / z 103(50 \%)$, and $m / z 104(50 \%)$ in the spectrum of the $\mathrm{CH}_{3} \mathrm{OH}-\mathrm{C}_{6} \mathrm{H}_{5} \mathrm{CN}$ mixture; and at $m / z 42(62 \%)$, $m / z .44(86 \%), m / z 46(100 \%), m / z 103(43 \%)$, and $m / z$ $105(19 \%)$ in the spectrum of the $\mathrm{CD}_{3} \mathrm{CN}-\mathrm{C}_{6} \mathrm{H}_{5} \mathrm{CN}$ mixture. The production of the protonated benzonitrile species therefore may be attributed mainly to the following reactions:

$$
\begin{gathered}
\mathrm{H}_{3}^{+}+\mathrm{C}_{6} \mathrm{H}_{5} \mathrm{CN} \rightarrow\left(\mathrm{C}_{6} \mathrm{H}_{5} \mathrm{CN}\right) \mathrm{H}^{+}+\mathrm{H}_{2} \\
\Delta \mathrm{H}_{\mathrm{r}}=-94 \mathrm{kcal} / \mathrm{mol}
\end{gathered}
$$

$$
\begin{gathered}
\mathrm{CH}_{3} \mathrm{OH}_{2}^{+}+\mathrm{C}_{6} \mathrm{H}_{5} \mathrm{CN} \rightarrow\left(\mathrm{C}_{6} \mathrm{H}_{5} \mathrm{CN}\right) \mathrm{H}^{+}+\mathrm{CH}_{3} \mathrm{OH} \\
\Delta H_{r}=-14 \mathrm{kcal} / \mathrm{mol} \\
\mathrm{CH}_{3} \mathrm{CNH}^{+}+\mathrm{C}_{6} \mathrm{H}_{5} \mathrm{CN} \rightarrow\left(\mathrm{C}_{6} \mathrm{H}_{5} \mathrm{CN}\right) \mathrm{H}^{+}+\mathrm{CH}_{3} \mathrm{CN} \\
\Delta H_{r}=-7 \mathrm{kcal} / \mathrm{mol}
\end{gathered}
$$

The MIKE spectra of the metastable ions were studied by selecting and focusing the $\left(\mathrm{C}_{6} \mathrm{X}_{5} \mathrm{CN}\right) \mathrm{X}^{+}$species into the second field-free region ( 2 FFR), that is, between the magnetic (B) and electric (E) analyzers, and scanning the voltage of E. CID/MTKE spectra were obtained by introducing $\mathrm{He}$ as target gas into the collision cell located in 2 FFR. The He pressure in the cell was varied over the range $3.5 \times 10^{-5}$ to $3.7 \times 10^{-4} \mathrm{mbar}$, as estimated [7] from the ionization gauge reading situated in this region.

Table 1. MIKE spectra of the $\mathrm{C}_{6} \mathrm{X}_{5} \mathrm{CNH}^{+}$metastable ions generated from various sources

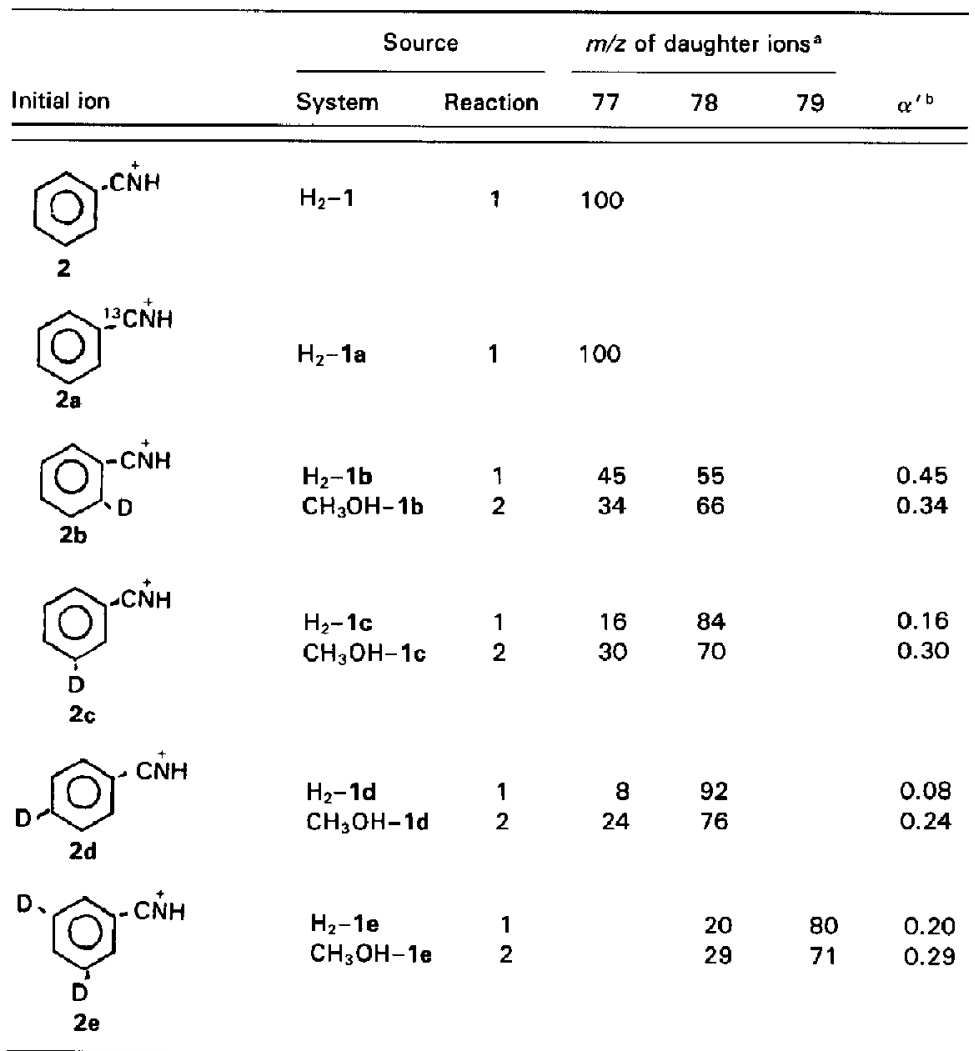

Abundances are expressed as percentages of the sum.

- Fraction of $D$ transferred from the phenyl ring to the nitrile group, expressed as the ratio $\alpha^{\prime}=$ $\mathrm{C}_{6} \mathrm{H}_{6-n} \mathrm{D}_{n-1}^{+} /\left(\mathrm{C}_{6} \mathrm{H}_{6-n} \mathrm{D}_{n-1}^{+}+\mathrm{C}_{6} \mathrm{H}_{5-n} \mathrm{D}_{n}^{+}\right)$. 
Table 2. MIKE spectra of the $\mathrm{C}_{6} \mathrm{X}_{5} \mathrm{CND}^{+}$metastable ions generated from various sources

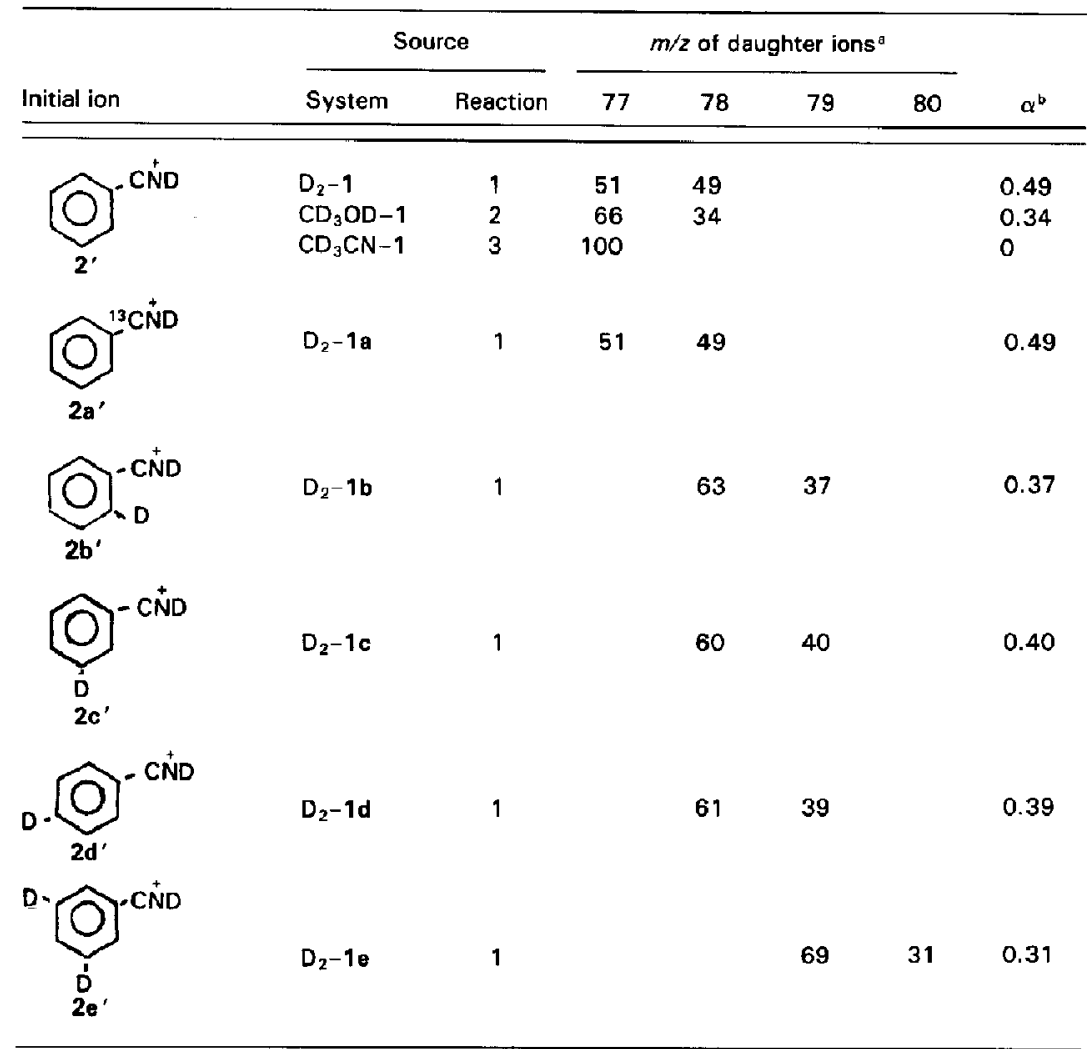

Abundances are expressed as percentages of the sum.

b Fraction of $D$ transferred from the nitrile group to the phenyl ring expressed as the ratio $\alpha=$ $\mathrm{C}_{6} \mathrm{H}_{5-n} \mathrm{D}_{n}^{+} /\left(\mathrm{C}_{6} \mathrm{H}_{5}{ }_{n} \mathrm{D}_{n}^{+}+\mathrm{C}_{6} \mathrm{H}_{6-n} \mathrm{D}_{n-1}^{+}\right)$.

\section{Materials}

Helium, $\mathrm{H}_{2}$, and $\mathrm{D}_{2}$ (Matheson), $\mathrm{CH}_{3} \mathrm{OH}$ (Aldrich), and $\mathrm{CD}_{3} \mathrm{OD}, \mathrm{CD}_{3} \mathrm{CN}$, and $\mathrm{C}_{6} \mathrm{H}_{5} \mathrm{CN}$ (Merck) were obtained commercially and were used without further purification. Carbon-13-labeled benzonitrile 1a was available from a previous study [8]. The D-labeled benzonitriles $1 \mathbf{b}-1 \mathrm{e}$ were obtained by dehydration [9] of the corresponding benzamides, which were available from an earlier study [10]. All labeled compounds 1a-1e were purified by GC using a silicone OV $1 \mathrm{col}-$ umn at $150{ }^{\circ} \mathrm{C}$.

\section{Results and Discussion}

The MI/MIKE spectrum of the protonated benzonitrile species 2 generated by reaction 1 shows (Table 1 ) only one ionic fragment observed at $m / z 77\left(\mathrm{C}_{6} \mathrm{H}_{5}^{+}\right)$, which arises from the metastable ion dissociation reaction

$$
\left(\mathrm{C}_{6} \mathrm{H}_{5} \mathrm{CN}\right) \mathrm{H}^{+} \rightarrow \mathrm{C}_{6} \mathrm{H}_{5}^{+}+(\mathrm{C}, \mathrm{H}, \mathrm{N})
$$

The MI spectra of the labeled ions $\left(\mathrm{C}_{6} \mathrm{H}_{5} \mathrm{CN}\right) \mathrm{D}^{+}\left(2^{\prime}\right)$ and $\left(\mathrm{C}_{6} \mathrm{H}_{5}{ }^{13} \mathrm{CN}\right) \mathrm{H}^{+}$(2a) prepared from $\mathrm{CD}_{3} \mathrm{CN}-1$ (re- action 3) and $\mathrm{H}_{2}-\mathbf{1 a}$ (reaction 1), respectively, show (Tables 1 and 2 ) that both $\mathrm{D}$ and ${ }^{13} \mathrm{C}$ are specifically eliminated in the $\left(C_{r} X, N\right)$. These results indicate that $\mathrm{H}^{+}$in $\left(\mathrm{C}_{6} \mathrm{H}_{5} \mathrm{CN}\right) \mathrm{H}^{+}$is attached to the $\mathrm{CN}$ group rather than to the phenyl ring.

As can be seen in Table 2, in the case of ions $\mathbf{2}^{\prime}$ generated from the $D_{2}-1$ (reaction 1) and $\mathrm{CD}_{3} \mathrm{OD}-1$ (reaction 2) systems, the formation of $\mathrm{C}_{6} \mathrm{H}_{4} \mathrm{D}^{+}(\mathrm{m} / \mathrm{z}$ 78) is observed in addition to that of $\mathrm{C}_{6} \mathrm{H}_{5}^{+}(\mathrm{m} / z 77)$.

Taking into account that CID experiments on the stable ions $2^{\prime}$ strongly support that they have been formed in reactions $1-3$ by $\mathrm{D}^{+}$attachment to the $\mathrm{CN}$ group only (see below), it follows that before fragmentation (reaction 4) the $\mathrm{CN}$-to-ring $\mathrm{H} / \mathrm{D}$ exchange occurs in the $\mathrm{C}_{6} \mathrm{H}_{5} \mathrm{CND}^{+}$species generated by reactions 1 and 2 . The thermochemical data (Table 3) predict that reactions 1 and 2 are more exothermic than reaction 3.

The observed fractions of $D$ transferred from the $C N$ group to the phenyl ring, expressed as the ratio

$$
\alpha=\mathrm{C}_{6} \mathrm{H}_{5-n} \mathrm{D}_{n}^{+} /\left(\mathrm{C}_{6} \mathrm{H}_{5-n} \mathrm{D}_{n}^{+}+\mathrm{C}_{6} \mathrm{H}_{6-n} \mathrm{D}_{n-1}^{+}\right)
$$

are different for ions $2^{\prime}$ generated from $D_{2}-1$ and $\mathrm{CD}_{3} \mathrm{OD}-1$ (Table 2). This can be attributed to the differ- 
Table 3. Heats of formation used in this work

\begin{tabular}{lcll}
\hline Species & $\begin{array}{c}\Delta H_{1298}^{0} \\
(\mathrm{kcal} / \mathrm{mol})\end{array}$ & Species & $\begin{array}{c}\Delta H_{\text {t298 }}^{0} \\
(\mathrm{kcal} / \mathrm{mol})\end{array}$ \\
\hline $\mathrm{CN}$ & 104.0 & $\mathrm{H}_{3}^{+}$ & 264.5 \\
$\mathrm{HCN}$ & 32.3 & $\mathrm{CN}^{+}$ & 428.9 \\
$\mathrm{HNC}$ & $48 \pm 2$ & $\mathrm{HCN}^{+}$ & 346 \\
$\mathrm{CH}_{3} \mathrm{CN}$ & 18 & $\mathrm{HNC}^{+}$ & 336 \\
$\mathrm{CH}_{3} \mathrm{OH}$ & -48.2 & $\mathrm{CH}_{3} \mathrm{CNH}^{+}$ & 195 \\
$\mathrm{C}_{6} \mathrm{H}_{5}$ & $79 \pm 1$ & $\mathrm{CH}_{3} \mathrm{OH}_{2}^{+}$ & 136 \\
$\mathrm{C}_{6} \mathrm{H}_{6}$ & 119.8 & $\mathrm{C}_{6} \mathrm{H}_{5}^{+}$ & 269.3 \\
$\mathrm{C}_{6} \mathrm{H}_{5} \mathrm{CN}$ & 52 & $\mathrm{C}_{6} \mathrm{H}_{6}^{+}$ & 233.2 \\
& & $\mathrm{C}_{6} \mathrm{H}_{5} \mathrm{CNH}^{+}$ & 222 \\
& & &
\end{tabular}

Source: All values taken from ref. 20 .

ences in the excess energy of $2^{\prime}$ formed in reactions 1 and 2. Moreover, these results reflect that the productdetermining step of the $\mathrm{CN}$-to-ring $\mathrm{H}^{+}\left(\mathrm{D}^{+}\right)$transfer is controlled more by the energy barrier than by the frequency factor. The magnitude of this barrier is probably relatively low (below $14 \mathrm{kcal} / \mathrm{mol}$ ), as can be inferred from the observed $\alpha$ values for ions $2^{\prime}$ together with the protonation exothermicities of reactions 1-3. The data in Table 4 clearly show that the H/D atoms in $\mathrm{C}_{6} \mathrm{H}_{5} \mathrm{CND}^{+}$derived from reaction 1 are not statistically equilibrated before loss of $(C, X, N)$. Complete statistical scrambling of $H / D$ in $2^{\prime}$ would lead to the ratio $\mathrm{C}_{6} \mathrm{H}_{4} \mathrm{D}^{+} / \mathrm{C}_{6} \mathrm{H}_{5}^{+}$of 5 , whereas the ratio found for both $\mathbf{2}^{\prime}$ and $2 \mathbf{a}^{\prime}$ is 0.96 , which corresponds to a value of 1 , assuming complete equilibration of $\mathrm{D}$ at the $\mathrm{CN}$ group and one $\mathrm{H}$ atom at the phenyl ring. The results obtained for other ions listed in Table 3 are quite similar to those obtained for $2^{\prime}$ and $2 \mathbf{a}^{\prime}$.

All these observations imply that the $H(D)$ atoms from an ortho position of the phenyl ring in the $\mathrm{CN}$ to-ring H/D exchange are mainly involved. To obtain additional information about the H/D exchange between the CN group and the phenyl ring, the extent of D transfer from the ortho, meta, and para positions to the CN group has been examined using the sitespecifically deuterated analogues $2 \mathbf{b}-2 \mathbf{e}$ (Table I).

As the MI spectra in Figures 1a-1e and Table 1 show, the fraction of $D$ transferred from the ring positions to the CN group, expressed as

$$
\alpha^{\prime}=\frac{\mathrm{C}_{6} \mathrm{H}_{6-n} \mathrm{D}_{n-1}^{+}}{\mathrm{C}_{6} \mathrm{H}_{6-n} \mathrm{D}_{n-1}^{+}+\mathrm{C}_{6} \mathrm{H}_{5-n} \mathrm{D}_{n}^{+}}
$$

decreases in the order ortho>meta $>$ para for the ions generated by both reactions 1 and 2 .

The large differences in the $\alpha^{\prime}$ values found for ions $\mathbf{2 b}-\mathbf{2} \mathbf{d}$ derived from reaction 1 reveal that $H / D$ exchange in the phenyl ring is far from equilibrium prior to unimolecular dissociation. A relatively high value of $\alpha^{\prime}$ observed for ions $2 \mathbf{b}$ generated from $\mathrm{H}_{2}-\mathbf{1 b}$, as compared to ions $2 \mathrm{c}$ and $\mathbf{2 d}$ (Table 1 ), strongly supports the conclusion on the favored ortho position in the CN-to-ring exchange. A mechanism involving the latter process in ions $\mathbf{2 b}$ is proposed in Scheme II.

In nitrogen-protonated benzonitrile, the charge can be delocalized via a resonance structure at the cyano carbon atom, so that the cyano group is likely to be no longer linear, thus permitting first a proton transfer from the cyano group to the ortho ring position $2 \mathbf{b} \rightarrow \mathbf{3 b}$, which then may be followed by a $1,2 \mathrm{H}$ or $\mathrm{D}$ shift to the ipso position to give intermediate $\mathbf{4 b}$. From this intermediate, $X C N$ can be eliminated via a 1,1 elimination, which is also a thermochemically favored process (Figure 2).

The $\mathrm{H}^{+}$transfer from the CN group to the ipso position and vice versa via the bridged form intermediate $3 \mathbf{b}^{\prime}$, as shown in Scheme III, is expected to be a high energy demanding process.

Table 4. The $\mathrm{H} / \mathrm{D}$ exchange between the $\mathrm{CN}$ group and the phenyl ring in the $\mathrm{C}_{6} \mathrm{X}_{5} \mathrm{CNX}^{+}$metastable ions generated from $\mathrm{X}_{2} / \mathrm{C}_{6} \mathrm{X}_{5} \mathrm{CN}$

\begin{tabular}{|c|c|c|c|c|c|c|}
\hline \multirow[b]{3}{*}{ Species } & \multicolumn{6}{|c|}{ Ratios } \\
\hline & \multicolumn{2}{|c|}{$\mathrm{C}_{6} \mathrm{H}_{4} \mathrm{D}^{+} / \mathrm{C}_{8} \mathrm{H}_{5}^{+}$} & \multicolumn{2}{|c|}{$\mathrm{C}_{6} \mathrm{H}_{3} \mathrm{D}_{2}^{+} / \mathrm{C}_{6} \mathrm{H}_{4} \mathrm{D}^{+}$} & \multicolumn{2}{|c|}{$\mathrm{C}_{6} \mathrm{H}_{2} \mathrm{D}_{3}^{+} / \mathrm{C}_{6} \mathrm{H}_{3} \mathrm{D}_{2}^{+}$} \\
\hline & Obs. & Stat. & Obs. & Stat. & Obs. & Stat. \\
\hline $2^{\prime}$ & 0.96 & $1^{\circ} ; 2^{b} ; 5^{c}$ & & & & \\
\hline $2 \mathbf{a}^{\prime}$ & 0.96 & $1^{a}: 2^{b} ; 5^{c}$ & & & & \\
\hline 2b' & & & 0.59 & $0.33^{\mathrm{a}} ; 0.5^{\mathrm{b}} ; 2^{\mathrm{c}}$ & & \\
\hline $2 c^{\prime}$ & & & 0.67 & $1 \mathrm{a} ; 2^{\mathrm{b}} ; 2^{\mathrm{c}}$ & & \\
\hline $2 d^{\prime}$ & & & 0.64 & $1^{\mathrm{a}} ; 2^{\mathrm{b}} ; 2^{\mathrm{o}}$ & & \\
\hline $2 \mathbf{e}^{\prime}$ & & & & & 0.45 & $1^{a} ; 2^{b} ; 1^{c}$ \\
\hline $2 b$ & 1.22 & $3.0^{0} ; 2^{b} ; 5^{c}$ & & & & \\
\hline
\end{tabular}



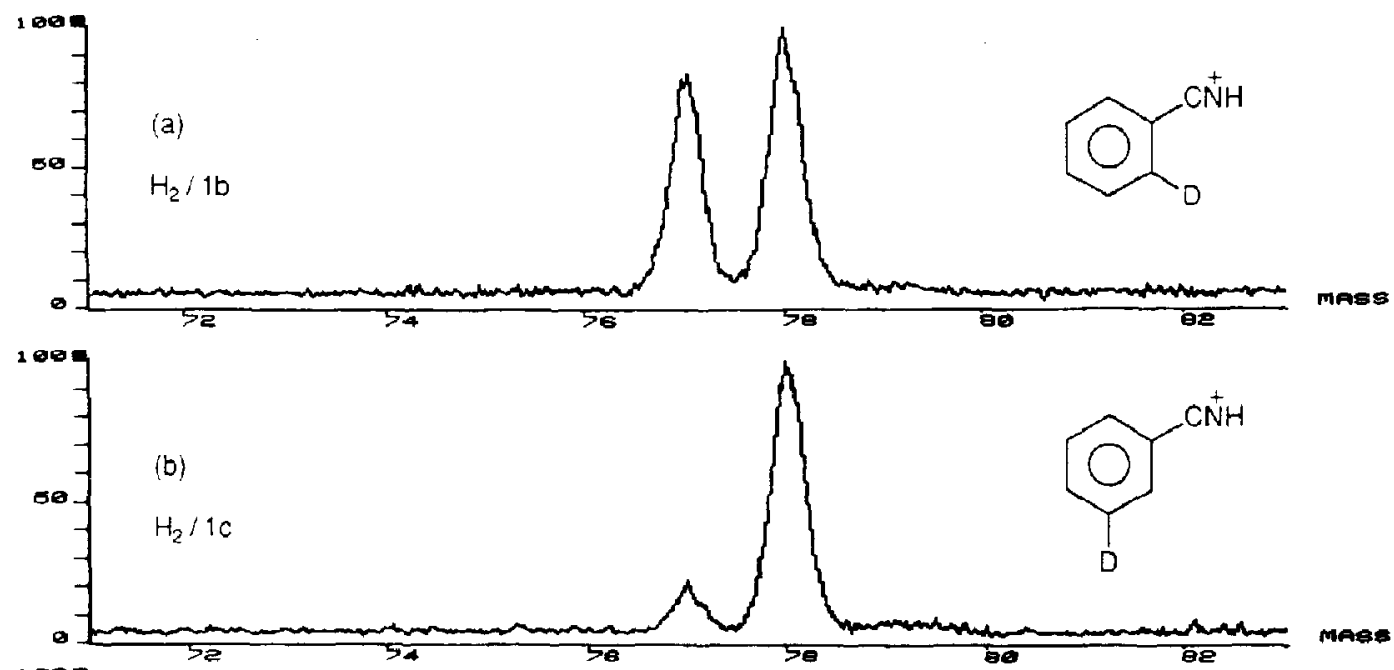

Mase
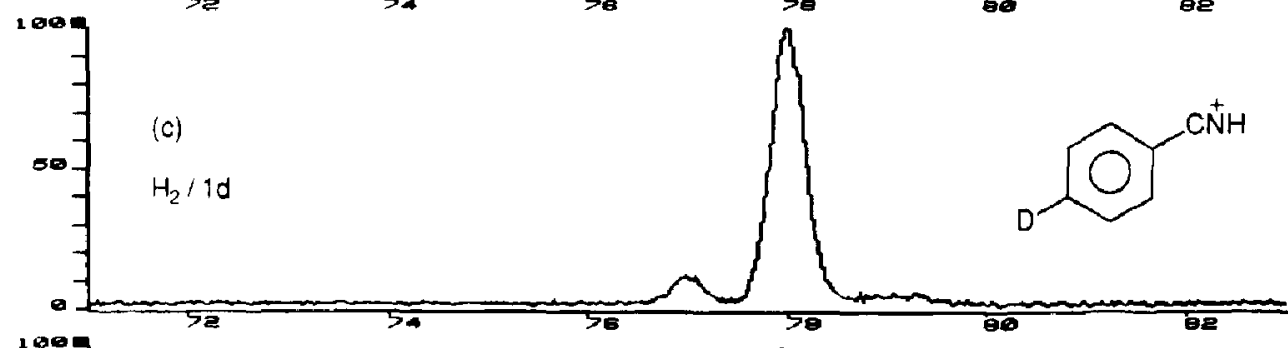

mase

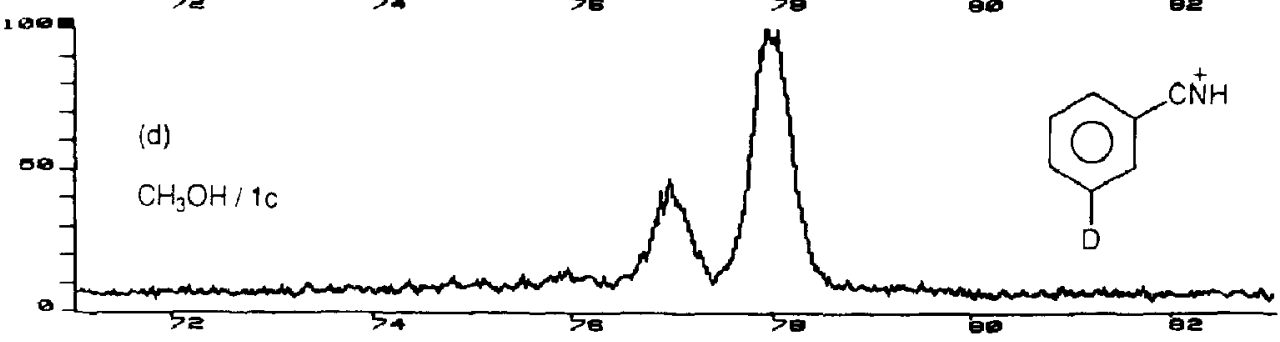

mares

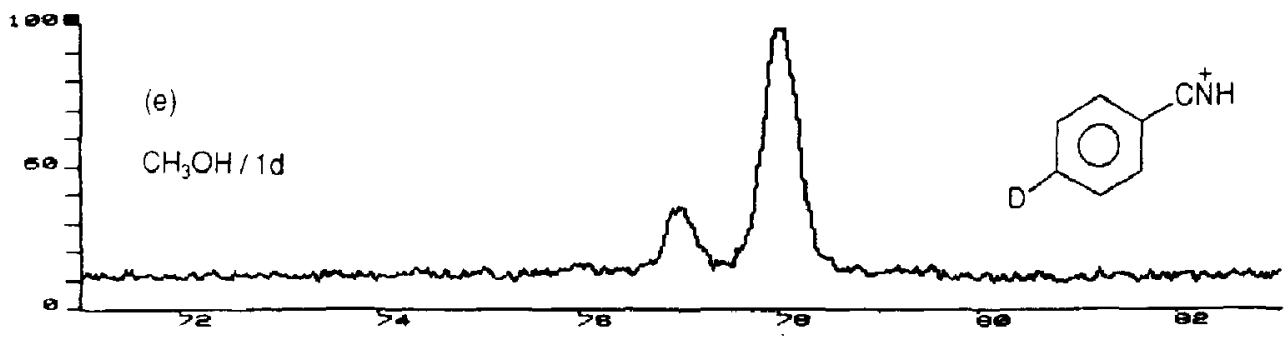

mage

Figure 1. Metastable dissociation spectra of $\mathrm{C}_{6} \mathrm{H}_{4} \mathrm{DCNH}^{+}$generated from the systems $(\mathrm{a}) \mathrm{H}_{3}^{+}\left(\mathrm{H}_{2}\right)-$ 1b, (b) $\mathrm{H}_{3}^{+}\left(\mathrm{H}_{2}\right)-1 \mathrm{c}$, (c) $\mathrm{H}_{3}^{+}\left(\mathrm{H}_{2}\right)-1 \mathrm{~d}$, (d) $\mathrm{CH}_{3} \mathrm{OH}_{2}^{+}\left(\mathrm{CH}_{3} \mathrm{OH}\right)-1 \mathrm{c}$, and (e) $\mathrm{CH}_{3} \mathrm{OH}_{2}^{+}\left(\mathrm{CH}_{3} \mathrm{OH}\right)-1 \mathrm{~d}$. The background pressure was $2 \times 10^{-9}$ mbar.

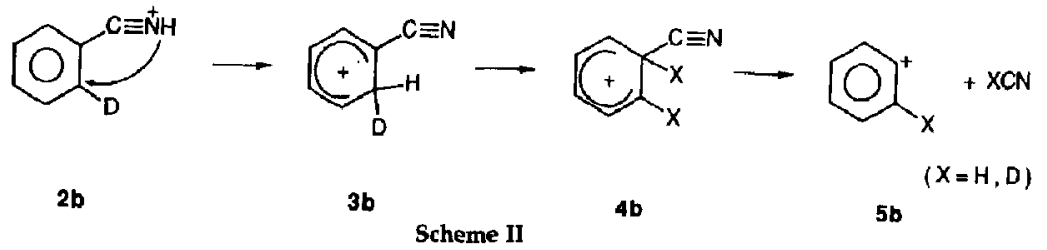




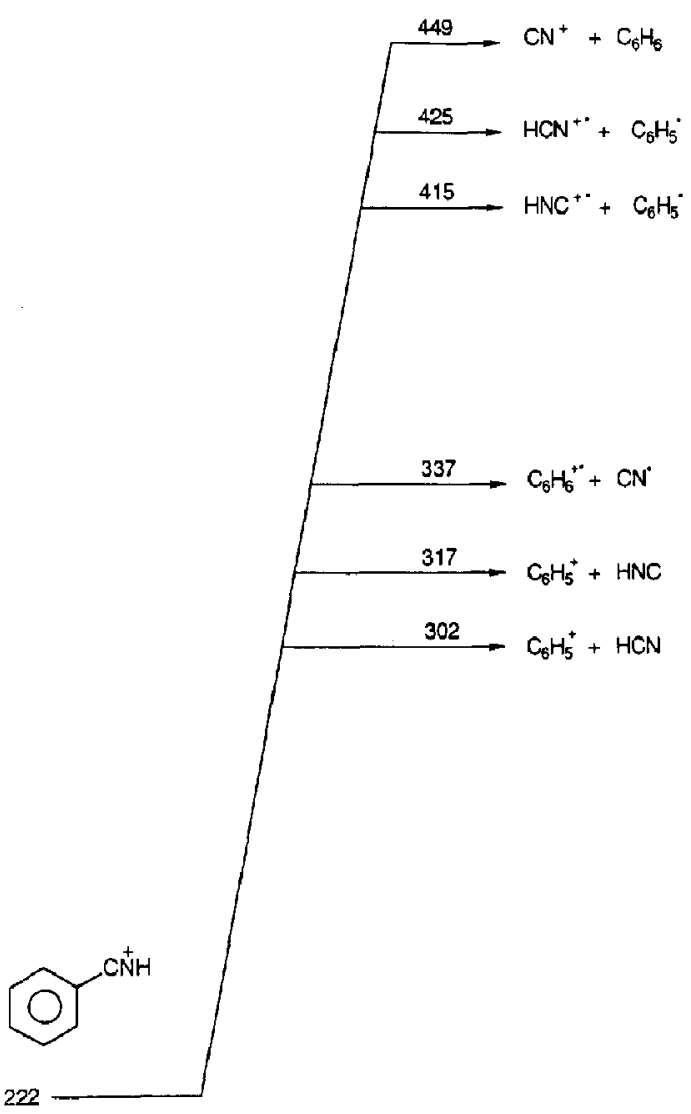

Figure 2. Thermochemical thresholds for the dissociation channels of $\mathrm{C}_{6} \mathrm{H}_{5} \mathrm{CNH}^{+}$obtained from the heats of formation given in Table 2 .

On the basis of the calculated barrier for conversion of $\mathrm{HNC}^{+} \cdot$ into $\mathrm{HCN}^{+} \cdot$ via a transition state resembling a complex of $\mathrm{H}^{+}$and $\mathrm{CN}$ [11], the critical energy for the route $\mathbf{2 b} \rightarrow \mathbf{3} \mathbf{b}^{\prime} \rightarrow \mathbf{4} \mathbf{b}^{\prime}$ should probably be in the range of 45-75 kcal/mol. Because our experiments imply a much lower value $(<14 \mathrm{kcal} / \mathrm{mol})$ for the CN-toring $H / D$ exchange barrier, it may be concluded that the mechanism shown in Scheme III is not operative.

Obviously, in the cases of ions $2 \mathbf{c}-2 \mathbf{e}$, the $\mathrm{H}^{+}$transfer through space from the $\mathrm{CN}$ group to the deuterated meta and para positions is expected to be less probable than transfer to the deuterated ortho position in $\mathbf{2 b}$, if it occurs at all, because of the large dis- tances to be overcome. It is more likely that in the ions $2 c-2 e$ the $\mathrm{CN}$-to-ring $\mathrm{H} / \mathrm{D}$ exchange proceeds by a pathway similar to that illustrated in Scheme II for ions 2b. After $\mathrm{H}^{+}$transfer from the $\mathrm{CN}$ group to the ortho ring position, the $H / D$ exchange may occur via 1,2 H/D shifts along the phenyl ring until eventually the intermediate $\mathbf{4 b}$ is formed from which XCN can be lost. Although the energy barrier for proton migration along the aromatic ring of ions 2 is not known, it is probably relatively low, judging by the reported activation energy of $10 \mathrm{kcal} / \mathrm{mol}$ for hydrogen scrambling in protonated benzene [12], the theoretically predicted [13] barrier of $7.7 \mathrm{kcal} / \mathrm{mol}$ between the $\pi$ and $\sigma$ complexes of this species and the estimated [14] barriers of $\sim 3-25 \mathrm{kcal} / \mathrm{mol}$ for the proton transfer between different ring positions in alkyl-substituted benzenium ions. One might expect, therefore, that the activation barrier for H/D exchange along the phenyl ring of ions $\mathbf{2 b - 2 e}$ is low enough (compared to that related to the loss of HCN, Figure 2) to reach a complete randomization prior to elimination of XCN. However, the fact that the observed $\alpha^{\prime}$ values depend on the initial position of the $\mathrm{D}$ atom in the phenyl ring (Table 1) indicates that this is not the case and suggests that the productdetermining step of the CN-to-ring H/D exchange in ions $2 c-2 e$ is associated with $H$ (D) migration along the phenyl ring. Moreover, these observations imply that the rate of this process is comparable to that of MI fragmentation (reaction 4), corroborating the reported slow $H / D$ exchange at the aromatic ring in metastably decomposing (3-phenyl-2-propynyl) benzenium ions and in protonated benzaldehydes and acetophenones [15] and being different from the reported $[14,16]$ complete $\mathrm{H} / \mathrm{D}$ exchange in the aromatic ring of benzenium ions prior to fragmentation.

The incomplete H/D exchange at the aromatic ring of ions $\mathbf{2 b - 2 e}$ versus the complete hydrogen scrambling in protonated benzene [16a] suggests that the cyano group has a significant influence on the rate of hydrogen migration along the phenyl ring.

STO-3G calculations [17] predict that the $\mathrm{CN}$ group destabilizes the cyclohexadienyl cation regardless of the site of substitution. Therefore, $\mathrm{H}^{+}\left(\mathrm{D}^{+}\right)$migration from the ring positions of the $3 b$-type intermediates toward the $\mathrm{CN}$ group-being a strong electronwithdrawing substituent and acting as $\pi$ base-rather than along the ring positions can be expected. This may lead to the limited H/D exchange at the phenyl ring seen in ions $\mathbf{2 b - 2 e}$.

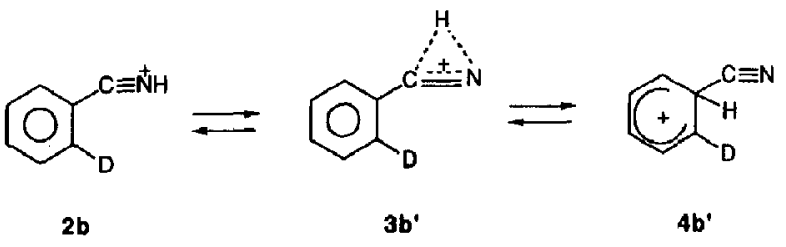

Scheme III 


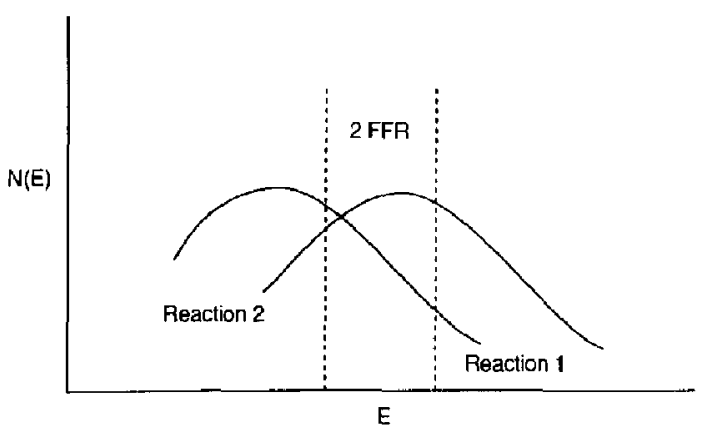

Figure 3. Schematic representation of the internal energy distribution for ions generated from reaction $1\left(\mathrm{H}_{3}^{+}+\mathrm{C}_{6} \mathrm{H}_{5} \mathrm{CN} \rightarrow\right.$ $\left.\mathrm{C}_{6} \mathrm{H}_{5} \mathrm{CNH}^{+}+\mathrm{H}_{2}\right)$ and reaction $2\left(\mathrm{CH}_{3} \mathrm{OH}_{2}^{+}+\mathrm{C}_{6} \mathrm{H}_{5} \mathrm{CN} \rightarrow\right.$ $\left.\mathrm{C}_{6} \mathrm{H}_{5} \mathrm{CNH}^{+}+\mathrm{CH}_{3} \mathrm{OH}\right)$.

Interestingly, while the $\alpha^{\prime}$ and $\alpha$ values for ions $\mathbf{2 b}$ and $\mathbf{2}^{\prime}$, respectively, are greater if they have been generated via reaction 1 rather than via reaction 2 , the reverse is true for ions $2 \mathrm{c}-2 \mathrm{e}$ (Tables 1 and 2). This effect may be interpreted in terms of a competition between $\mathrm{H} / \mathrm{D}$ exchange and elimination of $\mathrm{XCN}$. If the rates of $\mathrm{H}^{+}\left(\mathrm{D}^{+}\right)$transfer from the $\mathrm{CN}$ group to the phenyl ring $(2 \rightarrow 3 b)$ and $H / D$ exchange within intermediate $3 b$ relative to fragmentation in the metastable time window are markedly dependent on the internal energy, then ions generated by different $\mathrm{CI}$ reactions and having different internal energy distributions in this time window may lead to differences in the extent of $\mathrm{CN}$-to-ring $\mathrm{H} / \mathrm{D}$ exchange.

Taking into account the exothermicities of reactions 1 and 2, it is reasonable to expect that the internal energy distribution of metastable ions arising from reaction 1 would be shifted to higher energy compared to those from reaction 2, as illustrated in Figure 3.

In the case of ions $2 c-2 e$, the $\mathrm{CN}$-to-ring H/D exchange efficiency will depend mainly on the relative rates of $H / D$ exchange at the phenyl ring versus dissociation by loss of XCN. Since the barrier for H/D exchange is much lower than the threshold for elimination of XCN, the internal energy increase will greatly favor dissociation according to RRKM theory [18]. Thus, relative to dissociation, the rate of exchange will decrease with increasing internal energy of the reacting ions, giving the lower $\alpha^{\prime}$ values for the $\mathrm{CN}$-to-ring $\mathrm{H} / \mathrm{D}$ exchange. This is precisely the behavior exhibited by ions $2 \mathrm{c}-2 \mathrm{e}$ derived from reactions 1 and 2 (Table 1). However, the situation is somewhat different for ions $\mathbf{2}$ and $\mathbf{2} \mathbf{b}$, where, as mentioned above, the extent of $\mathrm{CN}$-to-ring exchange found for ions derived from reaction 1 is higher than for those from reaction 2 ( $\mathrm{Ta}-$

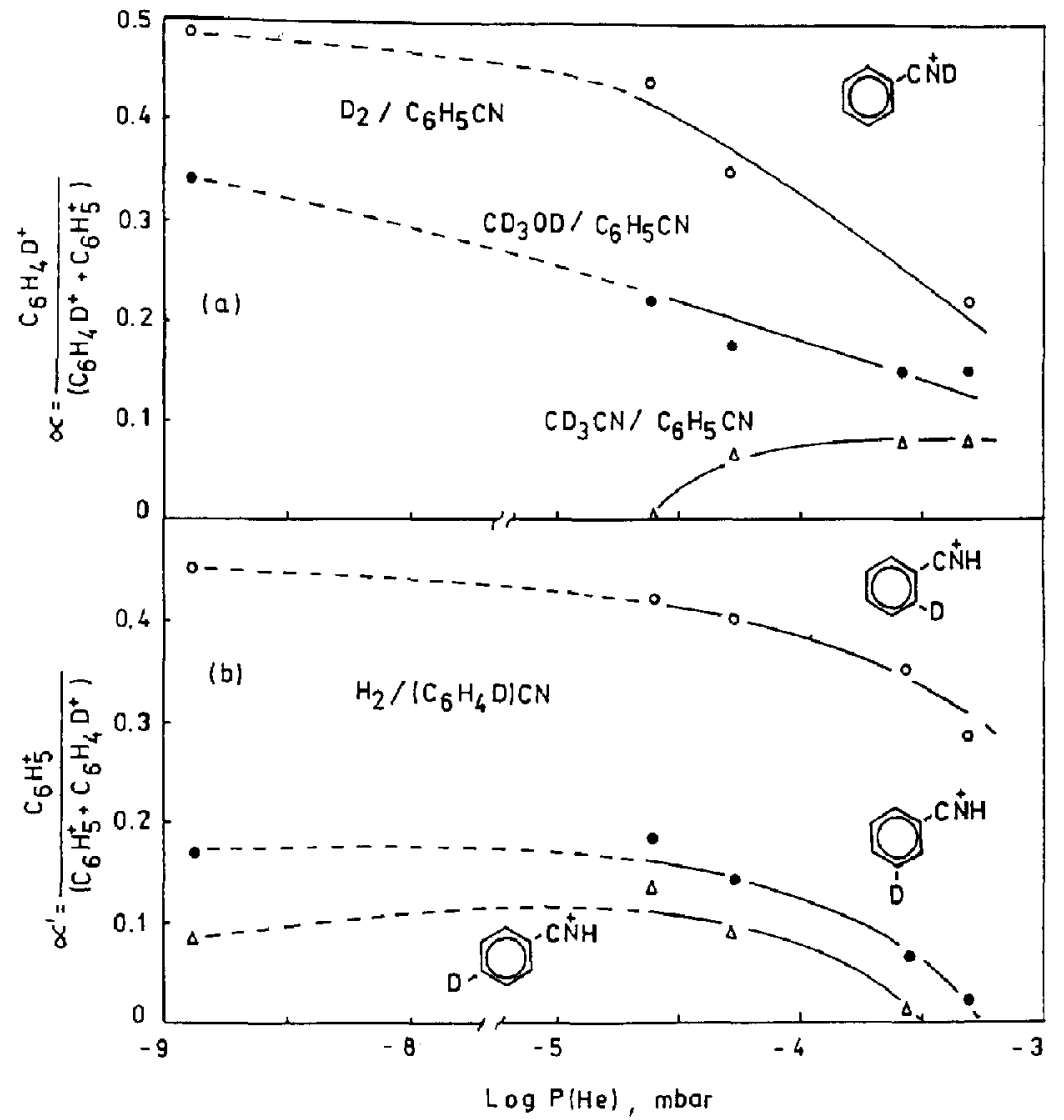

Figure 4. (a) The ion current ratios $\alpha=\mathrm{C}_{6} \mathrm{H}_{4} \mathrm{D}^{+} /\left(\mathrm{C}_{6} \mathrm{H}_{4} \mathrm{D}^{+}+\mathrm{C}_{6} \mathrm{H}_{5}^{+}\right)$for $\mathrm{C}_{6} \mathrm{H}_{5} \mathrm{CND}^{+}$generated from $\mathrm{D}_{3}^{+}\left(\mathrm{D}_{2}\right)-$ $\mathrm{C}_{6} \mathrm{H}_{5} \mathrm{CN}$ (O); $\mathrm{CD}_{3} \mathrm{OD}_{2}^{+}\left(\mathrm{CD}_{3} \mathrm{OD}\right)-$ $\mathrm{C}_{6} \mathrm{H}_{5} \mathrm{CN}$ (O) and $\mathrm{CD}_{3} \mathrm{CND}^{+}$ $\left(\mathrm{CD}_{3} \mathrm{CN}\right)-\mathrm{C}_{6} \mathrm{H}_{5} \mathrm{CN}(\triangle)$ as a function of the collision gas ( $\mathrm{He}$ ) pressure. (b) The ion current ratios $\alpha^{\prime}=\mathrm{C}_{6} \mathrm{H}_{5}^{+1}$ $\left(\mathrm{C}_{6} \mathrm{H}_{5}^{+}+\mathrm{C}_{6} \mathrm{H}_{4} \mathrm{D}^{+}\right)$for the $\mathrm{C}_{6} \mathrm{H}_{4}$. $\mathrm{DCNH}^{+}$ions indicated (generated from $\left.\mathrm{H}_{3}^{+}\left(\mathrm{H}_{2}\right)-\mathrm{C}_{6} \mathrm{H}_{4} \mathrm{DCN}\right)$ as a function of the collison gas (He) pressure. The values at $P(\mathrm{He})=2 \times$ $10^{-9}$ mbar correspond to background pressure. 
bles 1 and 2). This can be understood if the H/D exchange between the $\mathrm{CN}$ group and the ortho ring position is controlled predominantly by the energy barrier associated with the $\mathrm{H}^{+}\left(\mathrm{D}^{+}\right)$transfer process, $\mathbf{2} \rightarrow \mathbf{3 b}$ (Scheme II), which at lower protonation exothermicities can no longer compete effectively with dissociation of the $\left(\mathrm{C}_{6} \mathrm{H}_{5} \mathrm{CN}\right) \mathrm{H}^{+}$ions via reaction 4 .

It should be added that the results of the present work support the earlier observations [19] indicating the influence of the internal energy distribution on metastable ion decompositions in 2 FFR.

Further information on the hydrogen migration in the protonated benzonitrile species has been obtained from the CID/MIKE spectra. As can be derived from Figure $4 a$, upon $\mathrm{CID}$, ion $2^{\prime}$ prepared from $\mathrm{CD}_{3} \mathrm{CN}-\mathrm{C}_{6} \mathrm{H}_{5} \mathrm{CN}$ undergoes, in contrast to spontaneous dissociation, $\mathrm{CN}$-to-ring $\mathrm{H} / \mathrm{D}$ exchange as manifested by the observed ratio $\alpha=$ $\mathrm{C}_{6} \mathrm{H}_{4} \mathrm{D}^{+} /\left(\mathrm{C}_{6} \mathrm{H}_{4} \mathrm{D}^{+}+\mathrm{C}_{6} \mathrm{H}_{5}^{+}\right)$as a function of the target gas pressure, $P(\mathrm{He})$. The behavior of $\alpha$ with $P(\mathrm{He})$ displayed in Figure 4a reflects the fact that as the internal energy of the reacting ions generated by reactions 1 and 2 is increased by increasing the number of collisions (by increasing the collision gas pressure), the formation of $\mathrm{C}_{6} \mathrm{H}_{4} \mathrm{D}^{+}$becomes less competitive with respect to that of $\mathrm{C}_{6} \mathrm{H}_{5}^{+}$. These observations together with the $\alpha$ values found for metastably decomposing ions 2 ' generated from reactions 1-3 (Table 2) suggest that highly excited (by collisional activation) protonated benzonitrile species undergo a direct dissociation by HNC loss. The thermochemical threshold for $\mathrm{C}_{6} \mathrm{H}_{5}{ }^{+}+\mathrm{HNC}$ formation is higher in energy than that for $\mathrm{C}_{6} \mathrm{H}_{5}{ }^{+}+\mathrm{HCN}$ formation (Figure 2). Therefore, it may well be that ions having a relatively high internal energy react via the direct and entropically favored process $2 \rightarrow \mathrm{C}_{6} \mathrm{H}_{5}^{+}+\mathrm{HNC}$. From Figure 4 it follows that the probability of this process increases as the internal energy of the reacting ions increases. In addition, these experiments support the conclusion that proton attachment in the reactions of benzonitrile with the protonating agents such as $\mathrm{H}_{3}^{+}, \mathrm{CH}_{3} \mathrm{OH}_{2}^{+}$, and $\mathrm{CH}_{3} \mathrm{CNH}^{+}$occurs at the $\mathrm{CN}$ group.

\section{Acknowledgments}

H. W. thanks the Netherlands Organization for Scientific Research (NWO) for providing a visitor's grant and the Polish Central Program for Pure Research CPBP-01.19 for financial support. R. H. F. and N. M. M. N. thank the Netherlands Organization for Scientific Research (SON/NWO) for continuous support. All of us are indebted to Mrs. T. A. Molenaar-Langeveld for the synthesis and purification of the labeled compounds studied.

\section{References}

1. (a) Benoit, F. M.; Harrison, A. G. Org. Mass Spectrom. 1976, 11, 599, 1056. (b) Benoit, F. M.; Harrison, A. G.; Lossing, F.
P. Org. Mass Spectrom. 1977, 12, 78. (c) Leung, H. W.; Harrison, A. G. Org. Mass Spectrom. 1977, 12, 582. (d) Benoit, F. M.; Harrison, A. G. J. Am. Chem. Soc. 1977, 99, 3980. (e) Kuck, D.; Bäther, W.; Grützmacher, H.-F. J. Am. Chem. Soc. 1979, 101, 7154. (f) Kuck, D.; Grützmacher, H.-F. Z. Naturforsch. 1979, 34b, 1750. (g) Zwinselman, J. J.; Nibbering, N. M. M.; Ciommer, B.; Schwarz, H. In Tandem Mass Spectrometry; F. W. McLafferty, Ed.; Wiley: New York, 1983; chapter 4. (h) Groenewold, G. S.; Gross, M. L. In Ionic Processes in the Gas Phase; Almoster Ferreira, M. A., Ed.; D. Reidel: Dordrecht, 1984; pp 243-265. (i) Fornarini, S.; Speranza, M. J. Am. Chem. Soc. 1985, 107, 5358. (j) Bäther, W.; Kuck, D.; Grützmacher, H.-F. Org. Mass Spectrom. 1985, 20, 589. (k) Schwarz, H. In The Chemistry of the Cyclopropyl Group; Rappoport, Z., Ed.; Wiley: New York, 1987; chapter 4. (1) Harrison, A. G. Org. Mass Spectrom. 1987, 22, 637. (m) Grützmacher, H.-F.; Thielking, G. Org. Mass Spectrom. 1988, 23, 397.

2. Freiser, B. S.; Woodin, R. L.; Beauchamp, J. L. I. Am. Chem. Soc. 1975, 97, 6893 .

3. Lau, Y. K.; Kebarle, P. J. Am. Chem. Soc. 1976, 98, 7452.

4. Meot-Ner (Mautner), M.; Karpas, Z.; Deakyne, C. A. J. Am. Chem. Soc. 1986, 108, 3913.

5. Wincel, H.; Fokkens, R. H.; Nibbering, N. M. M. Int. J. Mass Spectrom. Ion Processes 1989, 88, 241.

6. Wincel, H.; Fokkens, R. H.; Nibbering, N. M. M. Int. J. Mass Spectrom. Ion Processes 1989, 91, 339.

7. Lange, W. de.; Nibbering, N. M. M. Int. I. Mass Spectrom. Ion Processes 1988, 86, 287.

8. Molenaar-Langeveld, T. A.; Fokkens, R. H.; Nibbering, N. M. M. Org. Mass Spectrom. 1986, 21, 15.

9. Campagna, F.; Cavotti, A.; Casini, G. Tetrahedron Lett. 1977, 1813.

10. Bruins, A. P.; Nibbering, N. M. M.; Boer, T. J. de Tetrahedron Lett. 1972, 1109.

11. Koch, W.; Frenking, G.; Schwarz, H. Naturwissenschaften 1984, 71, 473.

12. Olah, G. A.; Schlosberg, R. H.; Kelly, D. P.; Mateescu, G. D. J. Am. Chem. Soc. 1970, 92, 2546.

13. Sordo, T,; Bertran, J.; Canadell, E. J. Chem. Soc., Perkin Trans. $1979,2,1486$.

14. Bäther, W.; Grützmachęr, H.-F. Int. J. Mass Spectrom. Ion Processes 1985, 64, 193.

15. (a) Bäther, W.; Kuck, D.; Grützmacher, H.-F. Org. Mass Spectrom. 1985, 20, 572. (b) Filges, U.; Grützmacher, H.-F. Org. Mass Spectrom. 1986, 21, 673; 1987, 22, 444.

16. (a) Bruins, A. P.; Nibbering, N. M. M. Org. Mass Spectrom. 1976, 11, 950. (b) Kuck, D.; Bäther, W. Org. Mass Spectrom. 1986, 21, 451 .

17. (a) McElvey, J. M.; Alexandratos, S.; Streitwieser, A., Jr.; Abboud, J. L. M.; Hehre, W. J. J. Am. Chem. Soc. 1976, 98, 244. (b) Paddon-Row, M. N.; Santiago, C.; Houk, K. N. J. Am. Chem. Soc. 1980, 102, 6561.

18. Forst, W. Theory of Unimolectlar Reactions; Academic: New York, 1973.

19. (a) Harrison, A. G.; Gäumann, T.; Stahl, D. Org. Mass Spectrom. 1983, 18, 517. (b) Reiner, E. J.; Poirier, R. A.; Peterson, M. P.; Csizmadia, I. G.; Harrison, A. G. Can. J. Chem. 1986, 64,1652

20. Lias, S. G.; Bartmess, J. E.; Liebman, J. F,; Holmes, J. L.; Levin, R. D.; Mallard, W. G. J. Phys. Chem. Ref. Data Suppl. 1988, 17. 